\title{
Fe 基アモルファス膜を用いた磁気弾性歪センサ
}

\author{
学生員申光 鎬 (東 北大) \\ 正員 井上光 輝 (豊橋技科大) \\ 正員荒井賢一 (東北大)
}

\section{Magnetoelastic Strain Sensors Fabricated with Fe-base Amorphous Films}

\author{
Kwang-Ho Shin, Student Member (Tohoku University) \\ Mitsuteru Inoue, Member (Toyohashi University of Technology) \\ Ken-Ichi Arai, Member (Tohoku University)
}

\begin{abstract}
Amorphous FeCoSiB films with high magnetomechanical coupling factors were studied to determine their strain sensitivities. In terms of the application of the magnetoelastic strain sensor element, we prepared the meander patterns of the films utilizing the photolithography and ion milling processes. The impedance change of the patterned films by a strain was measured in the frequency range from $1 \mathrm{MHz}$ to $1 \mathrm{GHz}$. The film patterns were subjected to a strain by bending of their substrates, which caused the change in the magnetic anisotropy of films via magnetoelastic coupling. Reflecting the excellent magnetomechanical coupling properties, the high frequency impedance of films were changed considerably: the change in impedance of $110 \%$ was observed at $500 \mathrm{MHz}$ by strain. The film patterns exhibited the figure of merit $F=(\Delta Z / Z) / \varepsilon$ (change in film impedance $Z$ per unit strain $\varepsilon$ ) of $2.6 \times 10^{5}$. It is also demonstrated that, utilizing the strain-dependent impedance, a small strain of $1 \times 10^{-7}$ can be detected with the film pattern.
\end{abstract}

キーワード：FeCoSiB アモルファス薄膜，磁気機械結合特性，高周波インピーダンス，磁気弹性歪センサ

\section{1. まえがき}

アモルファス磁性材料がもつユニークな特性として軟磁 気特性之高磁歪の共存がある.この材料は本質的に結晶磁 気異方性をもたずまたマクロな構造の均一性から磁壁ピン ニングの原因となる結晶粒界, ボイド, 析出などが存在し ないので, 優れた軟磁気特性を示す.さらに,これらの材 料のうち鉄基のものは大きな磁丕 $\left(\sim 40 \times 10^{-6}\right)$ を示す. 即ち, 材料に印加した小さい磁界によって大きい歪が発生すると ともに，比較的に小さな応力によって磁気特性が大きく変 化する，いわゆる優れた磁気機械結合特性をもつ.これを 最初見出したのは荒井らであった. 彼らは FeSiB アモルフ アスリボンの磁気機械結合係数が結晶質磁歪材料の数倍に 達する 0.75 という極めて大きい值を示すことを明らかにし た(1)(2). その後, Modzelewski らによって 0.96 という極めて 高い磁気機械結合係数が, FeSiBCアモルファスリボンで見 出された (3)。これらの材料は優れた磁気拱械結合特性をもつ ことで固体アクチュエータ, 歪や圧力などを測る機械量セ ンサ，磁界センサなどのセンシング材料として鬽力あると いえる(4)-(7)。しかし, 現在までは, その特質を利用した種々 のデバイスの実用化には至ってない。この理由は, リボン 材料の特性の制御が難しいこと,コイルの使用によって構
造が複雑となり，小型化が困難であることなどが考えられ るが, 最も主なのは鉄基アモルファス合金のもつ優れた磁 気機械結合特性を用いた電子デバイスを実用化するための 積極的考察が不充分であるためと考えられる.

一方, 強磁性体のインピーダンスが外部磁界に依存する ことは䄪 60 年前から知られている現象であり ${ }^{(8)}$,この現象 を利用した応用としてはインピーダンス制御回路(9)-(12), 平行 平板素子(13)等が報告されている. 1992 年毛利ら (14)によって アモルファスワイヤにおけるインピーダンスの外部磁界依 存性を用いたセンサの研究が行われて以来, この現象をマ イクロ磁界センサに応用しようとする研究が行われている (15)-(19). この現象の発生機構としては, 磁性材料の高周波に おける表皮効果が透磁率に依存することで説明されてきた (17)(18)，磁性材料の透磁率は外部磁界に依存するので, 結局 外部磁界により高周波における表皮効果が変わり，インピ 一ダンスが変化する. 磁歪を持つ材料の場合, 需が印加さ れると逆磁歪効果によってその透磁率が変わるので, 高周 波におけるインピーダンスが変化する.

本研究では，鉄基アモルファス磁性薄膜の磁気機械結合 特性を積極的に利用したマイクロ磁気弾性歪センサを提案 することを目的とし，アモルファス FeCoSiB 薄膜における 高周波インピーダンスが昰に対して敏感な依存性をもつこ 
とを明らかにした，本研究で提案した磁気弾性歪センサは， アモルファスリボンやワイヤなどのバルク材料をセンサ構 成材料として利用すると電極処理やセンサ実装などの取り 扱いが難しいことに注目して薄膜材料を用いているので， 取り扱いが容易で, 特性の再現性が高くかつ, 小型化も可 能である。.また，作製したセンサは，高周波におけるイン ピーダンスの歪依存性をその動作原理とする新しい利用方 法を用いた電気素子である.

\section{2. 実臨方法}

磁気弾性歪センサ用磁歪薄膜は，小さな歪に対して磁気 特性が敏感かつ大幅に変化するように, 高磁歪と軟磁気特 性を同時に有する, 即ち磁気機珹結合係数の大きいことと, 分散の少ない一軸誘導磁気異方性が形成できることが要求 される. Fe を多量含むアモルファス磁性材料は磁気機械結 合特性が優れているとともに第 2 の遷移金属を適当に添加 することで誘導磁気異方性の制御も可能である. 本研究で は磁気弾性歪センサ用の材料として $\left(\mathrm{Fe}_{90} \mathrm{Co}_{10}\right)_{76} \mathrm{Si}_{11} \mathrm{~B}_{13}$ アモ ルファス高磁歪薄膜を用いた. 薄膜作製方法としては $R F$ ス パッタ法を用いた．スパッタターゲットには， $99.99 \%$ の純 度を持つ $\mathrm{Fe}_{72} \mathrm{Si}_{14} \mathrm{~B}_{14}$ 合金ターゲット(直径 $75 \mathrm{~mm}$, 厚さ $4 \mathrm{~mm}$ ) に Co チップ $(4 \mathrm{~mm} \times 4 \mathrm{~mm}$, 厚さ $1 \mathrm{~mm})$ 配した複合ターゲッ 卜を用い, $3 \mathrm{~Pa}$ の $\mathrm{Ar}$ 票囲気で製膜を行った. 薄膜基板には 厚さ $1 \mu \mathrm{m}$ の酸化シリコンが熱酸化法で形成された $0.2 \mathrm{~mm}$ 厚の高抵抗シリコン基板 $(>1000 \Omega-\mathrm{cm})$ を用いた. 製膜中薄 膜に形成されるランダムな応力をリリースし，鉄基アモル ファス磁性材料本来の軟磁気特性を得るために磁界中熱処 理を行った. 薄膜の熱処理は $6.7 \times 10^{-4} \mathrm{~Pa}$ 以下の真空中で, $350^{\circ} \mathrm{C}, 40 \mathrm{kA} / \mathrm{m}$ の回転磁界中で 2 時間, $380^{\circ} \mathrm{C}, 40 \mathrm{kA} / \mathrm{m}$ 静 磁界中で 1 時間熱処理を施した. 熱処理後, 薄膜の飽和磁 歪を光てこ法 ${ }^{20}$ を用いて測定し，その值が的 $32 \times 10^{-6}$ であ ることを確認した．作製した薄膜素子の歪に対する高周波 インピーダンス変化を評価する目的で, フォトリソグラフ イ法とイオンミリング法により磁性膜を長さ $3 \mathrm{~mm}$, 幅 100 $\mu \mathrm{m}$, 厚さ $1,3,5 \mu \mathrm{m}$ の 7 ターン・ミアンダーライン状に 加エした.

アモルファス $\mathrm{FeCOSiB}$ 薄膜を歪の印加による高周波イン ピーダンス変化を利用するセンサとして使う場合, 出力電 圧を大きくし，センサ感度を上げるために適当な電気抵抗 值を付与する必要があり，薄膜を微細加工技術により，パ ターニングすることが必須である。しかし， $\mathrm{Fe}$ 系アモルフ アス材料は磁性原子ペアーオーダリングによる誘導磁気異 方性が小さく ${ }^{21}$, 飽和磁化が比較的に大きい（๙1.5T）ので 熱処理中大きな反磁界が発生することで薄膜が厚く, 膜パ ターン幅が狭い場合, 薄膜パターンの幅方向に磁気異方性 を誘導することは難しい，微細加工した磁気弾性歪センサ において磁気機械結合特性とともに静的磁化状態が歪検出 感度に影響を及ぼす主なパラメターであるので，その感度 を高めるために，誘導磁気異方性の制御が望ましい。従つ て, 本研究では材料の持つ本来の誘導磁気異方性に加えて,

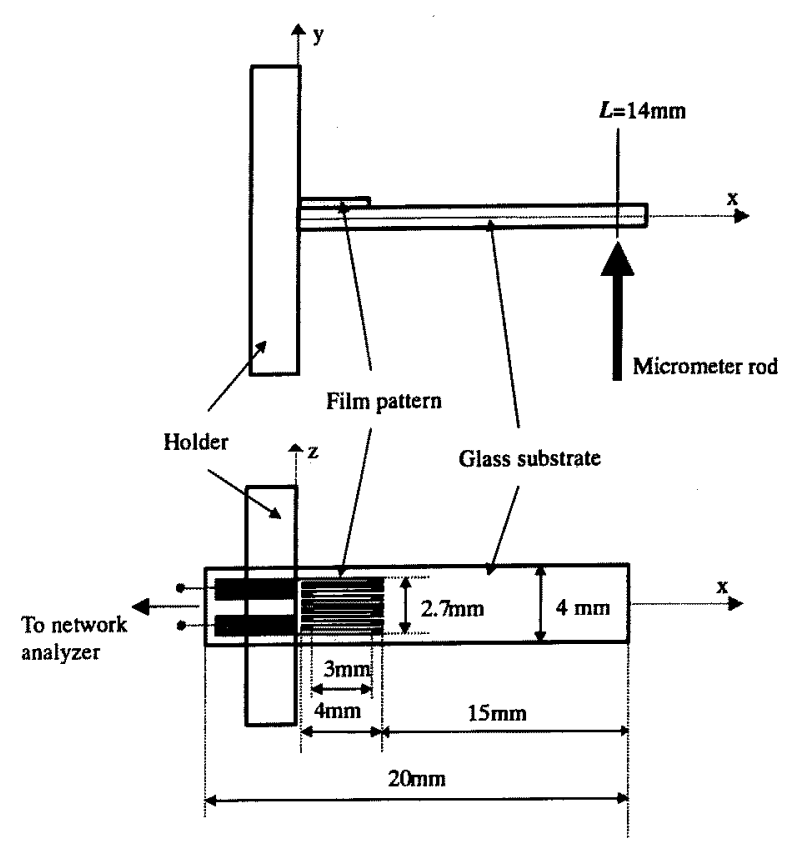

図 1 歪感度測定系

Fig.1 Experimental setup for measuring the strain sensitivity of films. The strain is introduced to the films by bending of the substrates.

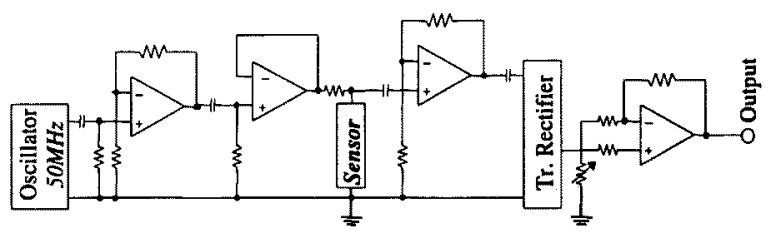

図 2 歪測定に用いたインピーダンス検出回路 Fig. 2 Impedance detection circuit for the magnetoelastc strain sensor.

逆磁歪効果を利用した磁気異方性の制御を可能とするバイ アス応力による磁気異方性の制御法を提案し, 薄膜パター ンの磁区観察によってその有用性について检討を行った.

逆磁歪効果を用いた薄膜パターンの磁気異方性を制御す るためのパイアス応力は, 薄膜基板をベンディングした状 態で膜パターンの幅方向に $40 \mathrm{kA} / \mathrm{m}$ の磁界を印加しながら 熱処理を行った後，基板の形状を元に戻すことで薄膜に掛 けた、ここで, 薄膜基板の長さは $18 \mathrm{~mm}$, 熱処理実施中基板 中間部のたわみは $50 \mu \mathrm{m}$ であった. 基板ベンディングによ り，薄膜にはパターンの長手方向に対して引張り応力が掛 かり,その状態で熱処理を行うと薄膜の微細構造が安定化 される. 熱処理後、基板をベンディングからリリースする と薄膜にはパターンの長手方向に対して圧樎力が掛かり， 磁化が幅方向を向くことになる. バイアス応力による磁気 異方性の大きさは，基板をベンディングすることで掛けた 応力による磁気弾性エネルギ $\left(1 / 2 \lambda_{s} \sigma: \lambda_{s}\right.$ は薄膜の飽和 磁歪值， $\sigma$ は応力）を考虑するし, 磁気暴方性エネルギ $\left(1 / 2 \mathrm{M}_{\mathrm{s}} \mathrm{H}_{\mathrm{k}}: \mathrm{M}_{\mathrm{s}}\right.$ は飽和磁化， $\mathrm{H}_{\mathrm{k}}$ は異方性磁界）に換算す るとバイアス応力が薄膜パターンの磁気異方性に寄与する 分が分かる.それによって計算される応力による磁気異方 
性の大きさは異方性磁界として約 $560 \mathrm{~A} / \mathrm{m}$ であった.

図 1 は $\mathrm{FeCoSiB}$ 薄膜の歪感度特性評価に用いた装置の概 略図を示す．磁丕薄膜を形成したシリコン基板をカンチレ バー状に固定し, その自由端にマイクロメータを用いて強 制的に微小変位を加えた. 図 1 に示したように, カンチレ バ状に構成した薄膜基板の固定点からの位置を $\mathrm{x}$ とした場

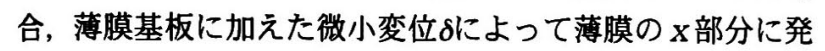
生する歪 $\varepsilon$ は式(1)によって記述できる(22).

$$
\varepsilon=\left[\frac{3 h(L-2 x)}{2 L^{3}}\right] \delta
$$

ここで, $h$ は薄膜基板の厚さ, $L$ は固定点から微小変位を 加えた位置までの距㒕である. 磁歪材料に歪を加えると応 カによる磁気異方性が誘導される.

作製した薄膜試料は, $1 \mathrm{MHz}$ から $1 \mathrm{GHz}$ までの周波数範囲 でネットワークアナライザにより, 歪に対する高周波イン ピーダンス変化を測定した. また, 薄膜素子と検出回路を 一体化した歪センサシステムを構成するため, 図 2 に示す インピータンス検出回路を作製し, 薄膜パターンの歪に対 する出力信号変化を調べた.

\section{3. 応カバイアスを用いた一軸磁気異方性の制御}

図 3 （a）(b)はそれぞれ磁界中熱処理を行った薄膜パター ンとバイアス応力を利用して熱処理を行った薄膜パターン の磁区を撮影した走查型影钽鏡 (SEM) 写真である. 薄膜の厚 さはいずれも $3 \mu \mathrm{m}$ であった. 図 3(a)の場合, 試料の幅方向 に磁界を印加しながら熱処理を行ったにも関わらず, 試料

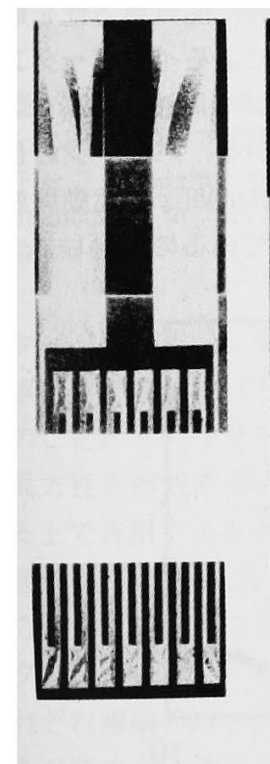

(a)
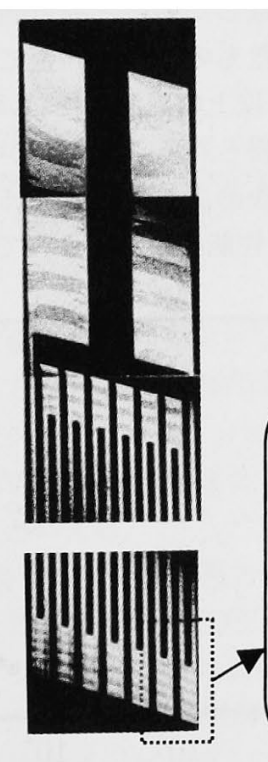

(b)
図 3 微細加工した膜パターンの磁区写真

Fig. 3 Magnetic domains of the film pattern annealed (a):in static magnetic field and (b):that of the film pattern annealed with bias stress.
の平均磁化方位が長手方向に向いていることがわかる. 熱 処理中磁界を印加した方向に磁気異方性が誘導されてない のは薄膜パターンの幅方向では形状異方性が大きいことと 誘導磁気異方性が小さいことが主な原因であると考えられ る.この結果からこの薄膜パターンに圧縮歪が印加された とき磁化回転によってインピーダンスの敏感な変化が予想 される. 図3(b)の場合, 試料の幅方向に磁化の向きが揃って いることが分かる. 磁界中熱処理によりアモルファス材料 に圧力が加えた状態で熱的駆動力による原子の微小変位の みならず, 機械的駆動力による構造の緻密化が起こること も考えられる. Shen ら(23)は $\left(\mathrm{Fe}_{10} \mathrm{Co}_{55} \mathrm{Ni}_{35}\right)_{78} \mathrm{Si}_{8} \mathrm{~B}_{14}$ アモルファ ス合金に等方的応力を加えながら熱処理を行い, キュリー 温度の変化と微小構造の緩和における応力の及ぼす影䈏に ついて調べた. その結果, キュリー温度が応力によって約 $0.4 \% / \mathrm{GPa}$ 低下することを確認し, 応力が構造緩和に影響を 及ほすことを確かめた. しかし、本研究での応力熱処理で は最高でも約 $0.15 \mathrm{GPa}$ の応力が熱処理中薄膜にかかること になるので, 応力による磁気異方性が磁気特性に及ぼす影 掣に比べて応力によるアモルファス構造緩和の影響はほと んど無視できると考えられる. 従って, 本研究でのバイア ス応力法による磁気異方性の制御は, 薄膜基板がベンティ

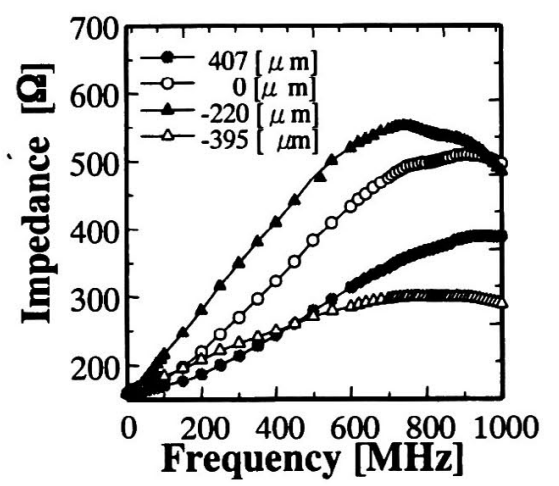

(a)

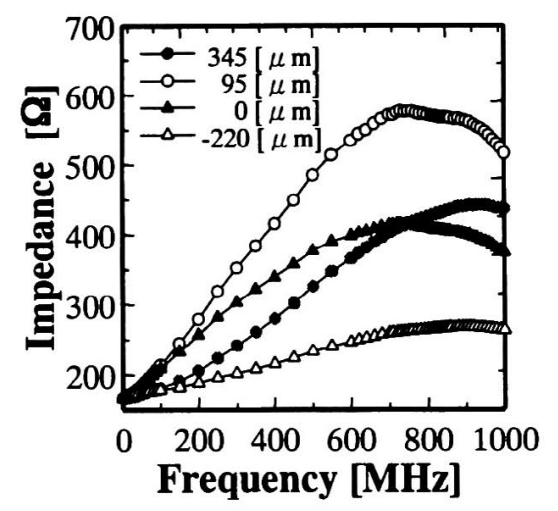

(b)

図 4 膜インピーダンスの周波数特性

Fig. 4 Frequency dependence of the Impedance, changed by substrate deflection; (a): longitudinal anisotropy, (b): transverse anisotropy. 
ングされた状態で熱処理を行いアモルファス棈造が安定化 されることと熱処理後ベンディングした基板を元の状態に 戻すことにより，パイアス応力が薄膜に掛かることが薄膜 パターンの異方性が制御できる機構であると考えられる.

この結果からバイアス応力を用いた熱処理によって磁気異 方性の制御が可能であることが分かる，この薄膜の場合， 磁化が薄膜パターンの幅方向に向いているので, 引つ張り 歪が印加されたとき, 磁化回転によりインピーダンスの敏 感な変化が予想される.

\section{4. 歪による高周波インピーダンスの変化}

図 4(a)，(b) は IMHz から $1 \mathrm{GHz}$ までの駆動周波数における 薄膜パターンのインピーダンスを測定した結果で, 印加し た終端変位をパラメータとして示したものであり,それぞ れ図 3(a)に示したように長手方向に磁気異方性を形成した ものと図 3(b)に示したように幅方向に磁気異方性を形成し たものである. 歪によるインピーダンス変化は薄膜基板を 図 1 に示したように固定し，マイクロメータを用いて微細 変位を加えながらネットワークアナライザを用いて測定し

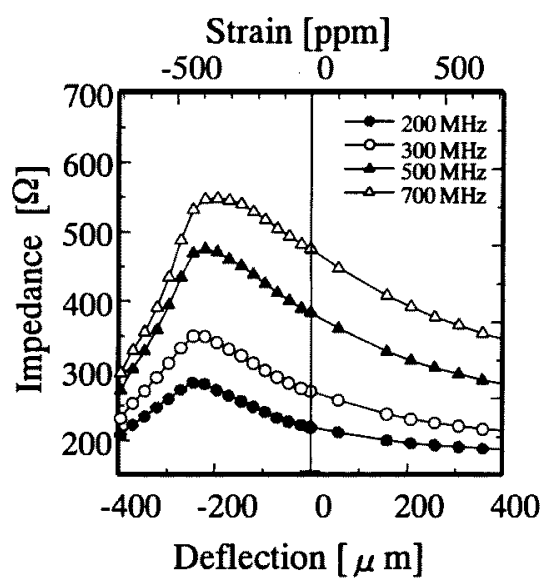

(a)

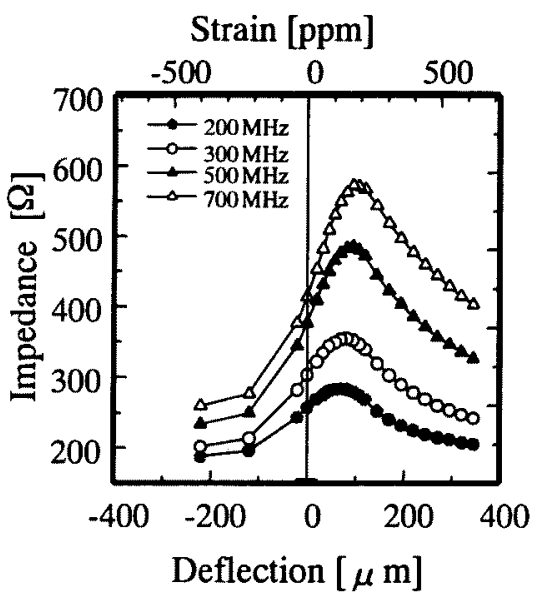

(b)

図 5 歪によるインピーダンスの変化

Fig. 5 Impedance change of the film pattern by deflection and/or strain; (a): longitudinal anisotropy, (b): transverse anisotropy.
た．同図から分かるように，歪により，約 $10 \mathrm{MHz}$ 以上の周 波数では終端の変位あるいは薄膜の歪によってインピータ ンスが変化する. このような歪の印加によるインピーダン スの変化は, 囸によって薄膜の磁気異方性が変わることで, 高周波における表皮効果の表皮厚さが変わり, その高周波 インピーダンスが変化したものと説明できる. 即ち, 歪に よる磁歪薄膜のインピーダンス変化は高周波における表皮 効果の透磁率体存性 $\delta=\left(2 \rho / \omega \mu_{0} \mu\right)^{1 / 2}$ によるものである. ここで， $\delta$ は表皮深さ， $\rho$ 電気抵抗率， $\mu$ は透磁率， $\omega$ は駆 動角周波数である. 高磁歪材料の場合加えた歪 $\varepsilon$ にって 透磁率が敏感に変化するので高周波電流をキャリアとした 場合, 薄膜の磁気弾性結合と表皮効果を通じてインピーダ ンスは歪により敏感な変化を示す. 図 5(a),(b)は歪に対す る磁歪薄膜パターンのインピーダンス変化を示したもので ある. 図 5(a)から分かるように，長手方向に磁気異方性を 形成した場合，圧縮歪の約 $100 \mathrm{ppm}$ に対するインピーダンス の変化 $\left(\Delta Z /\left|Z_{0}\right|=\left(\left|Z_{0}\right|-\left|Z_{\varepsilon}\right|\right) /\left|Z_{0}\right|: Z_{\varepsilon}\right.$ と $Z_{0}$ は其々歪が加 えられた状態と加えられてない状態のインピーダンス)は $500 \mathrm{MHz}$ の駆動周波数において約 6\%である. 図 5(b)に示し たように幅方向に磁気異方性を形成した場合, 引っ張り歪 の $100 \mathrm{ppm}$ に対するインピーダンスの変化は $500 \mathrm{MHz}$ の駆動 周波数において約 $22 \%$ である. この結果を図 3 の結果と比 較すると試料の幅方向に磁気異方性を形成することによっ て薄膜パターンのインピーダンスにおける歪感度が高くな ったことがわかる.

図 6 は薄膜パターンの単位歪に対するインピーダンスの 変化で定義する歪センシングにおける性能指数 $F=(\Delta Z / Z) / \varepsilon$ の周波数特性を示したもので, パターンの長手方 向に磁気異方性を形成したものと幅方向に磁気異方性を形 成したものを比較したものである. 歪によるインピーダン スの変化は約 $10 \mathrm{MHz}$ 以上の周波数において周波数が高くな ると高い性能指数が得られることが分かる. パターンの長 手方向に磁気異方性を形成したものは 500MH $\mathrm{z}$ の駆動周波 数において約 500 の性能指数が得られているのに対して,

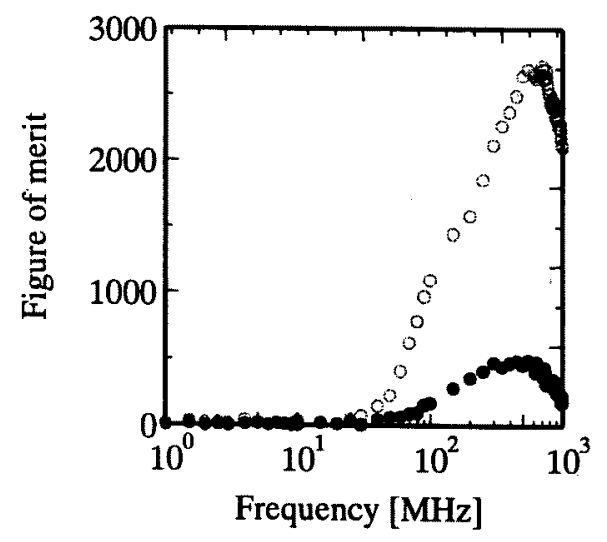

図 6 歪センシングにおける性能指数

Fig. 6 Figure of merit in a strain sensing; • : longitudinal anisotropy, $\mathrm{o:} \mathrm{transverse} \mathrm{anisotropy.}$ 


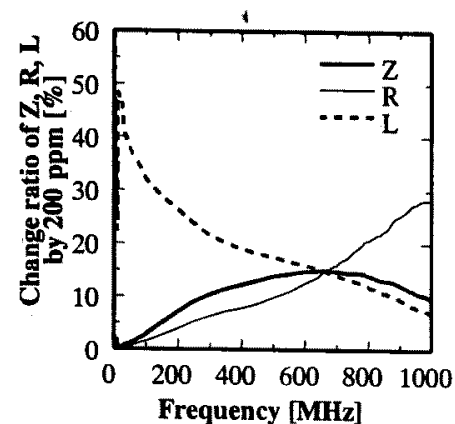

(a)

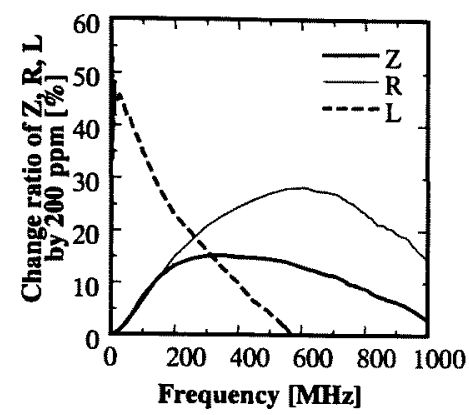

(b)

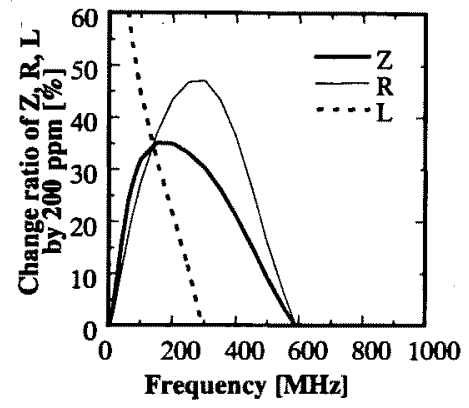

(c)

図 $7200 \mathrm{ppm}$ の歪によるインピーダンス，電気抵抗， インダクタンスの変化

Fig. 7 Changing ratio of the impedance, resistance and inductance in the film pattern; (a): $11 \mathrm{i} \mathrm{m}$, (b):3ì m, and (c):5ì m.

パターンの幅方向に磁気異方性を形成したものは $500 \mathrm{MH} \mathrm{z}$ の駆動周波数において約 2600 の性能指数が得られている.

このことからパイアス応力により，パターンの幅方向に磁 気異方性を形成するのは磁気弾性歪センサの歪感度を向上 する上で有用であるといえる。

図 7 (a) (b) (c) は長手方向に磁気異方性を持つ薄膜パター ンの歪センシングにおける 200ppm の圧縮歪に対するインピ ーダンス，抵抗，インダクタンスの変化を示したもので, それぞれ薄膜の厚さが $1,3,5 \mu \mathrm{m}$ のパターンの特性を比較し たものである. 歪によるインピーダンスの変化は歪によっ て透磁率あるいは高周波における表皮效果の変化から起因 するので, 薄膜の厚さが厚いほど比較的に低周波でインピ 一ダンスの変化が得られることが分かる．性能指数が最大 となる周波数は厚さ $1 \mu \mathrm{m}$ の試料の場合約 $620 \mathrm{MHz}$ ，厚さ 3 $\mu \mathrm{m}$ の試料の場合約 $450 \mathrm{MHz}$, 厚さ $5 \mu \mathrm{m}$ の試料の場合, 約

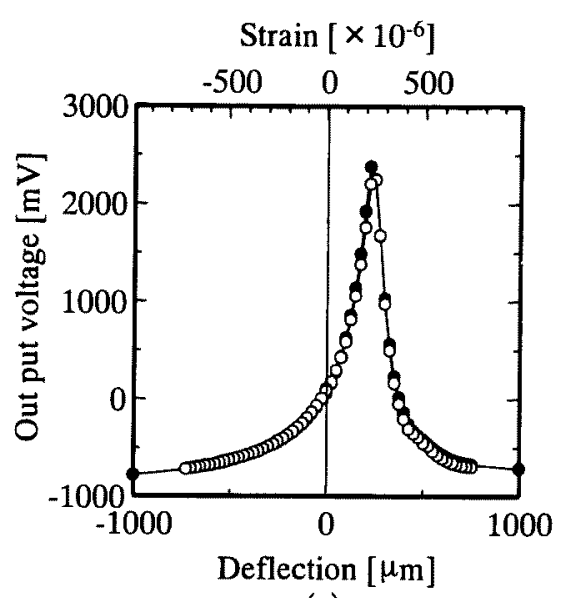

(a)

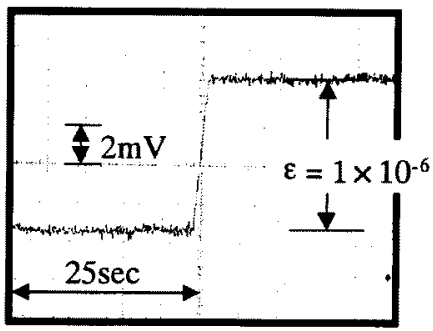

(b)

図 8 (a): 歪による出力電圧特性, (b): $1 \times 10^{-6}$ の 歪による出力信号の変化

Fig. 8 (a): Output voltage obtained with the film pattern and the substrate the strain detection circuit shown in Fig. 2, the strain induced by mechanical deformation of substrate. (b): Output voltage change by $1 \times 10^{-6}$ strain.

$300 \mathrm{MHz}$ であり, 薄膜パターンが厚いほど性能指数が最大と なる周波数が低くなることが分かる.最大性能指数は厚さ 1 $\mu \mathrm{m}$ の試料の場合約 220 , 厚さ $3 \mu \mathrm{m}$ の試料の場合約 500 , 厚 さ $5 \mu \mathrm{m}$ の試料の場合, 約 920 であった.このことから本研 究で提案する磁気弾性歪センサの歪感度を向上するために は駆動周波数によって薄膜パターンの寸法を設計する必要 があるといえる。

図 8（a）は図7（c）でその特性を示した厚さ $5 \mu \mathrm{m}$ の薄膜 パターンと図 2 に示したインピーダンス検出回路を利用し て素子に加えた終端変位に対する出力の変化を示したもの で, 終端変位に対して出力が連続的, かつ大きく変化して おり，作製した磁歪薄膜パターンが電生信号を出力する歪 センサとして動作することが分かる.図 8(b)は作製した磁歪 薄膜パターンとインピダンス検出回路を用いて $1 \times 10^{-6} の$ 歪を測定した結果で, 出力信号の変化をオシロスコープで 表示したものである. $1 \times 10^{-6}$ の歪に対して約 $8 \mathrm{mV}$ の出力 が得られた．この場合，ノイズレベルは $0.7 \mathrm{mV}$ であるので， 今回作製した磁歪薄膜とインピーダンス検出回路を用いて $1 \times 10^{-7}$ の歪検出が可能である. 


\section{5. まとめ}

微細加工した FeCoSiB アモルファス薄膜パターンのイン ピーダンスの歪依存性を評価し，磁気弾性効果を用いた歪 センサへの応用を試みた. 微細加工した薄膜試料は歪の印加 によってインピーダンスは, 薄膜パターンの長手方向に磁気異 方性を誘導した場合, 駆動周波数 $500 \mathrm{MHz}$ で約 $74 \%$, 薄膜パ ターンの幅方向に磁気異方性を誘導した場合, 駆動周波数 500 $\mathrm{MHz}$ で約 $110 \%$ の変化率を示し, 素子はインピーダンスの変化 からその歪を測定することができる電気素子として動作すること が分かった. 歪によるインピーダンスの変化から評価した歪セン シングにおける性能指数は薄膜パターンの幅方向に磁気異方 性を誘導した場合, 駆動周波数 $500 \mathrm{MHz}$ で約 2600 の值を示し, 作製した磁気弾性歪センサが, 半導体歪センサより 10 倍以上 高い歪感度特性を持つことが明らかになった. 磁気弾性歪セン サ検出用として作製した検出回路と磁歪薄膜パターンを用いて $1 \times 10^{-7}$ の歪のセンシングが達成できた. 本研究で提案した磁気 弾性歪センサは高感度と同時に, 高周波キャリアを用いるので 高速度であることと薄膜電気素子として小型も可能であるので, 新しい機械量を測るセンサやマイクロ電気機械システム(MEMS: microelectromechanical systems)を構成するセンサ素子として魅 カあるといえる.

(平成 11 年 6 月 14 日受付, 平成 11 年 10 月 4 日再受付)

\section{文献}

(1) K. I. Arai, N. Tsuya, M. Yamada, and T. Masumoto, IEEE Trans. Magn., Mag-12, (1976) 936.

(2) K. I. Arai, and N. Tsuya, J. Appl. Phys., 49 (1978) 1718.

(3) C. Modzelewski, H. T. Savage, L. T. Kabacoff, and A. E. Clark, IEEE Trans. Magn., Vol. MAG-17, (1981) 2837.

(4) P. T. Squire, Meas. Sci. Technol., 5 (1994) 67.

(5) A. Hernando, M. Vazquez, and J. M. Barandiaran, J. Phys., E:Sci. Instrum., 21 (1988) 1129.

(6) M. D. Mermelstein, IEEE Trans. Magn., Vol. 28, (1992) 36.

(7) M. Wun-Fogle, H. T. Savage, and A. E. Clark, InTech, (1987) 51.

(8) E. P. Harrison, G. L. Turney, H. Rowe, and H. Gollop, Proc. Roy. Soc., 157 (1937) 172.

(9) 今津信吾, 強磁性体の表皮効果によるインピーダンス制 御回路, 特願, 昭 36-41615.

(10) 津屋昇,荒井賢一，インダクタンスを含む電子装置,特願, 昭 52-66609.

(11) D. F. Othmer, J. Pipeline, 1, (1981) 113.

（12）沼沢茂, 村上孝一, 北條博行, 日本応用磁気学会誌, 9, (1985) 263.

(13) M. Yamaguchi, H. Matsuki, K. I. Arai, and K. Murakami, IEEE Tans. Magn., 25 (1989) 3824.

(14) K. Mohri, T. Kohzawa, K. Kawashima, H. Yoshida, and L. V. Panina, IEEE Trans. Magn., 28, (1992) 3150.
(15) X. L. Yang, J. X. Yang, G. Chen, G. T. Shen, B. Y. Hu, and K. Y. Jiang, J. Magn. Magn. Mater., Vol. 175, (1997) 285.

(16) K. V. Rao, F. B. Humphrey, and J. L. Costa-Kramer, J. Appl. Phys., Vol. 76, (1994) 6204.

(17) L. V. Panina, K. Mohri, K. Bushida, and Noda, J. Appl. Phys., Vol. 76, (1994) 6198.

(18) J. Velazqueq, M. Vasquez, D. X. Chen, and A. Hernando, Phys. Rev., B, Vol. 50, (1994) 16737.

(19) D. Mernard, M. Britel, V. P. Paramonov, A. S. Antonov, P. Ciureanu, P. Rudkowski, J. O, Strom-Olsen and A. Yelon, J. Appl. Phys., Vol. 81, (1996) 4678.

(20) H. Fujimori, H. Morita, Y. Obi, and S. Ohta, in Amorphous Magnetism II, edited by R. A. Levy and R. Hasegawa, (1977) 393.

(21) A. C. Tam and H. Schroeder, J. Appl. Phys., 64, (1988) 5422.

(22) I. Taher, M. Aslam, M. A. Tamor, T. J. Potter, and R. C. Elder: Sensors and Actuators, A45 (1994) 35.

(23) Zhong-Yi Shen, Jing-Xin Hong, Xiu-Jun Yin, Yun Zhang, and Shou-An He, J. Appl. Phys., 67 (1990) 3655.

申 光鐈 (学生員) 平成 5 年韓国東亜大学電気校工

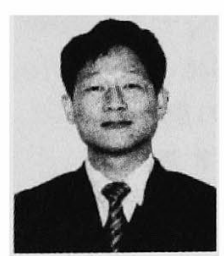
学科卒業. 平成 7 年韓国東亜大学電気校 工学科修士課程修了. 平成 11 年東北大学 大学院工学研究課電気通信工学専攻博士 課程修了. 現在, 医薬品副作用被害救済. 研究振興調查機構派遣研究員. 磁性薄膜 工学および磁気デバイスに関する研究に 従事. 応用磁気学会学術奖励賞 (武井賞) 受賞. 工博.

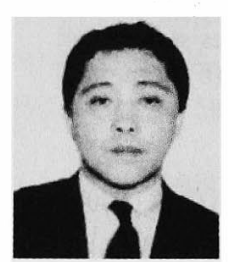

井上 光輝 (正員) 昭和 58 年豊橋 技術科学大学大学院修士課程了, 同年大 阪府立高専講師，同助教授を経て，平成 5 年豊橋技術科学大学工学部電気・電子 工学系講師, 平成 6 年同助教授, 現在に 至る.この間平

成 9,10 年東北大学電気通信研究所助教 授. 磁性薄膜工学および磁気デバイスに関する研究に従事. 安藤博学術奖励賞受賞. 工博.

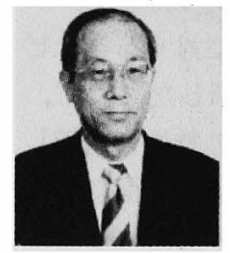

荒井 賢一（正員）昭和 41 年東北 大学工学部電子工学科卒業, 昭和 46 年同 学大学院工学研究科博士課程修了, 同年 同学電気通信研究所助手, 昭和 50 年同助 教授, 昭和 51 年同教授, 現在に至る. 主 として軟質磁性材料の研究およびマイク ロ磁気デバイス，マイクロ磁気センサ・アクチュエータなど のスピニックスデバイスの研究に従事. 